\title{
The Avocado (Persea americana Mill.) Leaf Extract on Streptozotocin-induced Pancreatic Cell Regeneration of White Rats (Rattus norvegicus)
}

\author{
Nurdin Rahman ${ }^{1 *}$, I. Made Tangkas ${ }^{1}$, Sri Muliyani Sabang ${ }^{2}$, Bohari Bohari ${ }^{3}$, Rukman Abdullah $^{4}$ (D) \\ ${ }^{1}$ Department of Nutrition, Faculty of Public Health, Universitas Tadulako, City of Palu, Indonesia; ${ }^{2}$ Department of Chemistry \\ Education, Faculty of Teacher Training and Education, Universitas Tadulako, City of Palu, Indonesia; ${ }^{3}$ Department of Nutrition, \\ Universitas Sultan Ageng Tirtayasa, City of Serang, Indonesia; ${ }^{4}$ Department of Medical Education, Universitas Sultan Ageng \\ Tirtayasa, City of Serang, Indonesia
}

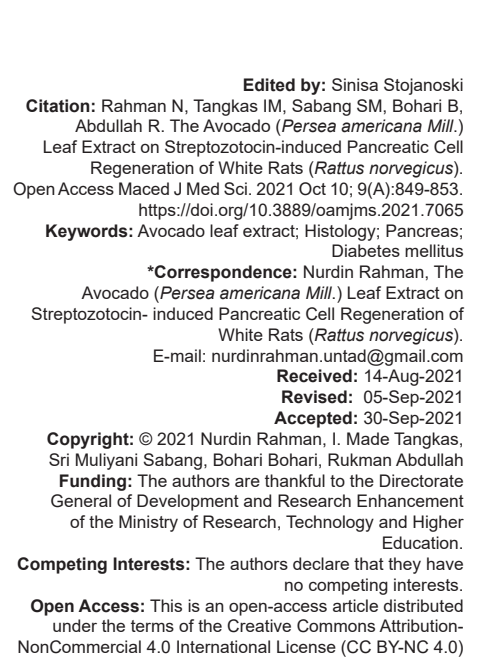

Abstract

AIM: The rate of pancreatic cell regeneration after avocado leaf extract intervention in a diabetic animal mode induced by streptozotocin (STZ) was investigated in this study.

METHODS: Experimental study was conducted on 18 male white rats as subjects, which were divided into six groups, three animals of each. Preparing diabetic animal models: First, the animals had been fasting a whole night; they were induced with STZ and 10\% sucrose. The primary data included the histopathology of the pancreas of white male rats in the form of histopathological scoring: Score 0: Normal, Score 1: 1-25\% pancreatic damage, Score 2: $25-50 \%$ pancreatic damage, Score 3: 50-75\% pancreatic damage, and Score 4: $70-100 \%$ pancreatic damage.

RESULTS: A dosage of $100 \mathrm{mg} / \mathrm{kg}$ b.w. of the ethanolic avocado leaf extract impacted pancreatic cells regeneration in white male rats, with a score of 1.67. However, improvement in pancreatic cell regeneration appears to increase align with the dose, score 1.00 in dosage of $150 \mathrm{mg} / \mathrm{kg} \mathrm{b.w.} \mathrm{and} \mathrm{score} 0.33$ in dosage of $200 \mathrm{mg} / \mathrm{kg}$. The score of 0.33 was also seen in G5 (obtained glibenclamide) and G6 (normal healthy animal). However, the most damage was in G4 who obtained only $0.5 \% \mathrm{Na}-\mathrm{CMC}$

CONCLUSION: The dose of $200 \mathrm{mg} / \mathrm{kg}$ b.w. of the avocado leaf extract contributed the most significant recovery of pancreatic cell of diabetic animal induced with STZ, equivalent to glibenclamide.

\section{Introduction}

Diabetes mellitus (DM) is a metabolic syndrome of failure in carbohydrate, fat, and protein metabolism caused by insulin deficiency or decreased tissue sensitivity to insulin [1]. This metabolic disease is characterized by hyperglycemia and disorders of carbohydrate, fat, and protein metabolism caused by abnormal insulin secretion and action results in blood glucose levels exceeding normal. DM is classified into two, type 1 diabetes that is dependent on insulin, and type 2 diabetes that is not dependent on insulin [2].

According to the International Diabetes Federation, DM prevalence globally is $1.9 \%$ and become the seventh cause of death. In 2012, the incidence of DM in the world was 371 million people, where the proportion of the incidence of type 2 DM $95 \%$ of the world's population suffers from DM. The Indonesian Basic Health Research (In Indonesian:
Riset Kesehatan Dasar) in 2008 showed that the prevalence of DM in Indonesia had grown to $57 \%$ [3]. The high prevalence of type $2 \mathrm{DM}$ is caused by several unchangeable risk factors, such as gender, age, genetic factors, body, waist circumference, and age [4], [5], [6]. This silent killer disease affects all organs and cause several complaints, including kidney disease, cataracts, impaired vision, heart disease, sexual impotence, gangrene, stroke, and others [7].

The state of diabetes or hyperglycemia will worsen and exacerbate ROS formation through several mechanisms in oxidative stress due to free radicals [8]. Oxidative stress and oxidative damage to tissues usually end up with chronic diseases including atherosclerosis, diabetes, and rheumatoid arthritis. It may increase glycosidation and lipoxidation in plasma and protein tissue due to the elevation of oxidative stress in DM [9], [10]. Diabetic ingredients such as alloxan can cause oxidative stress on cells and diabetic patients often experience oxidative stress. Complications of 
diabetes are related to oxidative stress, especially the formation of superoxide free radicals [11]. Sources of oxidative stress in diabetes include shifting the balance of redox reactions due to changes in carbohydrate and lipid metabolism which will increase the formation of ROS from glycation reactions and lipid oxidation, thereby reducing antioxidant defense systems including GSH [12]. Reducing oxidative stress is the most appropriate step by suppressing free radicals along with optimizing antioxidant intake [13]. Research shows that the use of dolichandrone atrovirens leaf and bark extract has blood glucose lowering potential action in diabetic conditions [2].

Antioxidants agents are needed in protecting and preventing cells against oxidative stress [14]. Medicinal plants are considered a source of various oxidative stress-related diseases [15], consisting of phenolic compounds, mainly in phenolic acids, flavonoids, and tannins. These compounds have a wide range of antioxidant activities [16]. Avocado leaves showed a potent in chelating free radicals related to antioxidant activities.

This study aims to analyze the effects of avocado leaf extracts on the pancreatic cell regeneration of people with diabetes.

\section{Methods}

\section{Material}

It was an in vivo experimental study through 18 white male rats (Rattus norvegicus) as subjects, conducted in the Pharmacology Laboratory of Pelita Mas Palu (STIFA) and Balai Besar Veteriner Maros. This study used avocado (Persea americana Mill.) leaves as the main materials.

\section{Extraction}

The collected avocado leaves were cleaned and sorted. The avocado leaves were then dried and crushed. The extract was prepared by maceration of crushed dried avocado leaves in $70 \%$ ethanol for 7 days. The extract obtained was concentrated by a rotary vacuum evaporator at $45^{\circ} \mathrm{C}$ and dried.

\section{Intervention}

There were six groups of animal experiments which consisted of three white rats in each group. The five rat's group rats had been diabetic animal models using (STZ), while one group was left as healthy normal rats. Preparing diabetic animal models: First, the animals had been fasting a whole night; they were induced with STZ and 10\% sucrose. After considering

diabetes, they were ready to be diabetic animal models. Each intervention of those groups was as follows:

1.

2.

3.

4.

5. G5: Feed + STZ $+10 \%$ sucrose + Glibenclamid $+0.5 \% \mathrm{Na}-\mathrm{CMC}$

6. G6: Normal healthy animal + regular feed

The surgical process was performed on the abdominothoracal part, followed by necropsy of the pancreas. The pancreas was then rinsed with $0.9 \%$ of physiological liquid of $\mathrm{NaCl}$ to separate it from the blood or fats attached to the organ.

\section{Data analysis}

The primary data included the histopathology of the pancreas of white male rats in the form of histopathological scoring: Score 0: Normal, Score 1: $1-25 \%$ pancreatic damage, Score 2: 25-50\% pancreatic damage, Score 3: $50-75 \%$ pancreatic damage, and Score 4: 70-100\% pancreatic damage.

\section{Ethical agreement}

The study approved by Health Research Ethics Committee of the Faculty of Medicine, Hasanuddin University Hospital, and Pulmonary General Hospital Dr. Wahidin Sudirohusodo, Makassar, with an ethical agreementNumber:546/H4.8.4.31/PP36-KOMETIK/2018.

\section{Results}

The results showed that the pancreatic sell damage in animal experimental was $\mathrm{G} 1=1.67$ (moderate cell damage); G2 = 1.00 (mild cell damage); G3 = 0.33 (no damage); $\mathrm{G} 4=3.00$ (severe cell damage); $\mathrm{G} 5=0.33$ (no damage); and G6 = 0.33 (no damage) (Table 1 and Figure 1).

A dosage of $100 \mathrm{mg} / \mathrm{kg} \mathrm{b.w}$. of the ethanolic extract of avocado impacted pancreatic cells

Table 1: Scoring pancreas histology damage

\begin{tabular}{lllll}
\hline Treatment groups & \multicolumn{4}{l}{ The score of pancreatic cell damage* } \\
\cline { 2 - 5 } & Animal 1 & Animal 2 & Animal 3 & Average \\
\hline G1 & 2 & 2 & 1 & 1.67 \\
G2 & 1 & 1 & 1 & 1.00 \\
G3 & 0 & 0 & 1 & 0.33 \\
G4 & 4 & 2 & 3 & 3.00 \\
G5 & 0 & 0 & 1 & 0.33 \\
G6 & 0 & 1 & 0 & 0.33 \\
\hline${ }^{*}=0:$ No damage, 1: Mild pancreatic cell damage (1/3 cell part), 2: Moderate pancreatic cell damage \\
(2/3 cell parts), 3: Severe pancreatic cell damage (>2/3 cell parts).
\end{tabular}




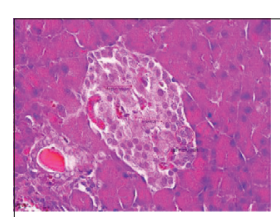

G1-1 (Score 2)

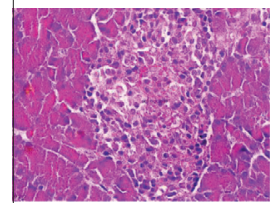

G2-1 (Score 1)

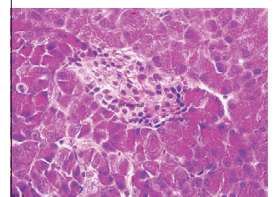

G3-1 (Score 0)

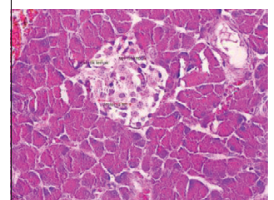

G4-1 (Score 4)

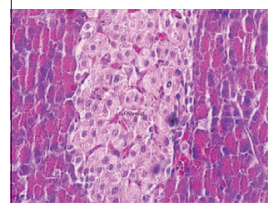

G5-1 (Score 0)

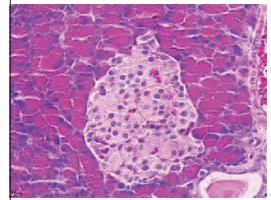

G6-1 (Score 0)

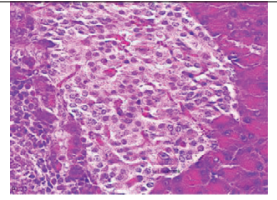

G1-2 (Score 2)

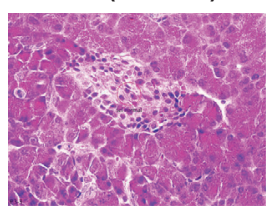

G2-2 (Score 1)

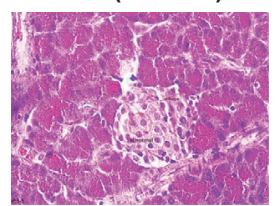

G3-2 (Score 0)

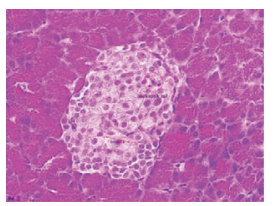

G4-2 (Score 2)

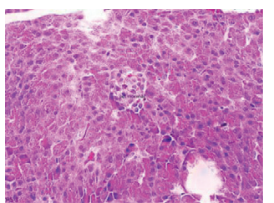

G5-2 (Score 0)

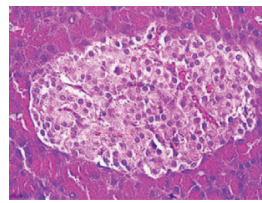

G6-2 (Score 1)

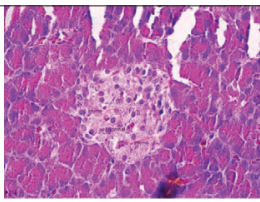

G1-3 (Score 1)

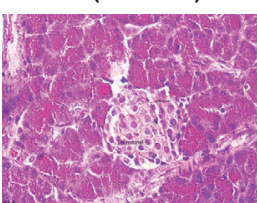

G2-3 (Score 1)

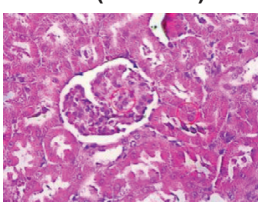

G3-3 (Score 1)

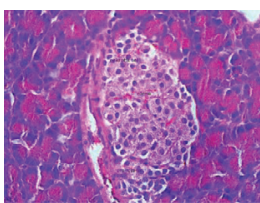

G4-3 (Score 3)

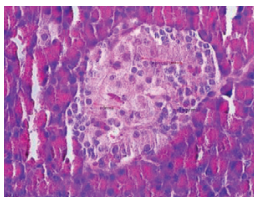

G5-3 (Score 1)

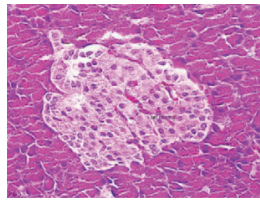

G6-3 (Score 0)

Figure 1: The level of damage of pancreatic cells

regeneration in white male rats, with a score of 1.67 . However, improvement in pancreatic cell regeneration appears to increase align with the dose, score 1.00 in dosage of $150 \mathrm{mg} / \mathrm{kg} \mathrm{b.w}$. and score 0.33 in dosage of $200 \mathrm{mg} / \mathrm{kg}$. The score of 0.33 was also seen in G5 (obtained glibenclamide) and G6 (normal healthy animal). However, the most damage was in G4 who obtained only $0.5 \% \mathrm{Na}-\mathrm{CMC}$.

\section{Discussion}

The results of pancreatic histology proven that multilevel dosages of avocado leaf extract effectively regenerate the kidney tissue of white male rats whose pancreas has been damaged by STZ induction, resulting in diabetes. It was seen that the higher dosage contributed more quickly to the regeneration of pancreatic cells in the STZ-induced DM animal model.

This recovery was seen to be most significant at a dose of $200 \mathrm{mg} / \mathrm{kg} \mathrm{b.w}$. (score 0.33 ) compared to the other two lower doses and had an effect equivalent to glibenclamide (0.33). However, cell regeneration was shown at doses of $100 \mathrm{mg} / \mathrm{kg}$ b.w. and $150 \mathrm{mg} / \mathrm{kg} \mathrm{b.w}$. (scores 1.67 and 1.00, respectively) compared to diabetic animal models receiving only NaCMC (3.00), the results did not match the effectiveness of glibenclamide.

Based on the observation of histopathological slides of the pancreas, there were cell degeneration and inflammation in pancreatic cells. The degeneration was occurred in the cytoplasm but did not harm the nucleus so that it may be recovered. The prolonged cell degeneration causes the cell inability to lead to improper metabolism, an initial reaction to acute cell damage caused by ischemia or toxin. The cell can regenerate and return its proper function when the toxic is neutralized or removed in a degenerative state. Cell degeneration is caused by the accumulation of toxic substances and other metabolites [17], [18].

The normal group (G6) of Langerhans islets did not show significant damage, and the shape was normal. Cell damage was seen in the negative control group (G4), which was indicated by the islets of Langerhans cells that looked empty, the small size of the Langerhans islets. The damage was caused by STZ induction, resulting in cell degeneration and pancreatic cell damage [19], [20].

Islets of Langerhans dominated by $\alpha$ cell compared to $\beta$ cell are caused by chronic hyperglycemic conditions that result in a decrease in insulin-producing cells and an increase in the activity of glucagonproducing cells [21]. The increase in insulin secretion previously described stated that the administration of glibenclamide in the positive control group could increase insulin secretion. This correlates with histopathological results that show the large Langerhans islets that can induce insulin secretion, although cell regeneration has not occurred in its entirety, and islet conditions are dominated by cells. The use of glibenclamide can inhibit oxidative stress and cell damage in the pancreas [22]

Administration of glibenclamide in experimental animals with diabetes can also prevent a decrease in insulin secretion and maintain or increase the number of glucagon-producing cells. In addition, the effectiveness of using glibenclamide is higher in stabilizing blood glucose levels than insulin therapy and can normalize cell damage that occurs in pancreatic islets [21].

The G3 group did not show any significant abnormalities and almost resembled the normal group. It indicated that the administration of water extract of Surian leaf at a dose of $200 \mathrm{mg} / \mathrm{kg} \mathrm{b.w}$. is more effective in inducing cell regeneration and inhibiting oxidative stress and pancreatic cell damage. Phytochemical compounds contained in avocado leaf extract have a role as a protective agent for pancreatic cells. The phytochemical screening test 
shows these compounds in avocado leaf extract [23]. Flavonoid is a phytochemical compound that effectively repairs and protects cell structures and is an antiinflammatory [24], [25]. Dembinska-Kiec et al. stated that flavonoid compounds' antioxidant activity in various plants could act as protective agents by reducing lipid peroxidation activity, increasing insulin secretion, and increasing glutathione and beta-carotene levels in the plasma of diabetic rats [26], [27]. The results of the study are in line with the previous studies which showed that the treatment of G3 with a dose of $200 \mathrm{mg} / \mathrm{kg}$ body weight avocado leaf extract gives a relatively effective influence on regenerating STZ induced renal cell rats, compared to other doses [28].

Other research shows that among the two phytoisolates of Swertia alata, the compound SA-4 has high anti-inflammatory potential and offers less ulcerogenic and less gastric irritant effect [29]. The results of this study imply that avocado leaf extract can be used and developed as a source of antioxidants that play a role in the regeneration of pancreas cells that degenerate due to high blood glucose levels.

\section{Conclusion}

The dose of $200 \mathrm{mg} / \mathrm{kg}$ body weight of the ethanolic avocado leaf extract contributed the most significant recovery of the pancreatic cell of diabetic white rats induced with STZ, which was equivalent to glibenclamide.

\section{References}

1. Chawla A, Chawla R, Jaggi S. Microvasular and macrovascular complications in diabetes mellitus: Distinct or continuum? Indian J Endocrinol Metab. 2016;20(4):546-51. https://doi. org/10.4103/2230-8210.183480

\section{PMid:27366724}

2. Kayarohanam S, Subramaniyan V, Janakiraman AK, Kumar SJ. Antioxidant, antidiabetic, and antihyperlipidemic activities of dolichandrone atrovirens in albino wistar rats. Res J Pharm Technol. 2019;12(7):3511-6. https://doi. org/10.5958/0974-360x.2019.00597.3

3. Kementerian Kemenkes RI. Main Results of Riskesdas 2018. Indonesia: Kementerian Kesehatan RI; 2018.

4. Harding AH, Day NE, Khaw KT, Bingham S, Luben R, Welsh A. Dietary fat and the risk of clinical type 2 diabetes: The European prospective investigation of Cancer-Norfolk study. Am J Epidemiol. 2004;159(1):73-82. https://doi.org/10.1093/aje/ kwh004

PMid:14693662

5. Hastuti RT. Faktor-faktor Risiko Ulkus Diabetika Pada Penderita Diabetes Melitus Studi Kasus di RSUD Dr. Moewardi Surakarta. Semarang: Universitas Diponegoro; 2008. https://doi. org/10.32382/jmk.v11i1.1072

6. Teixeira-Lemos E, Nunes S, Teixeira F, Reis F. Regular physical exercise training assists in preventing type 2 diabetes development: Focus on its antioxidant and anti-inflammatory properties. Cardiovasc Diabetol. 2011;10:12. https://doi. org/10.1186/1475-2840-10-12

PMid:21276212

7. Venkateshan S, Subramaniyan V, Chinnasamy V, Chandiran S Anti-oxidant and anti-hyperlipidemic activity of Hemidesmus indicus in rats fed with high-fat diet. Avicenna J Phytomed. 2016;6(5):516-25.

PMid:27761421

8. Matough FA, Budin SB, Hamid ZA, Alwahaibi N, Mohamed J. The role of oxidative stress and antioxidants in diabetic complications. Sultan Qaboos Univ Med J. 2012;12(1):5-18. https://doi.org/10.12816/0003082

PMid:22375253

9. Phaniendra A, Jestadi DB, Periyasamy L. Free radicals: Properties, sources, targets, and their implication in various diseases. Indian J Clin Biochem. 2015;30(1):11-26. https://doi. org/10.1007/s12291-014-0446-0 PMid:25646037

10. Fuloria S, Subramaniyan V, Karupiah S, Kumari U, Sathasivam K, Meenakshi DU. Comprehensive review of methodology to detect reactive oxygen species (ROS) in Mammalian species and establish its relationship with antioxidants and cancer. Antioxid Basel Switz. 2021;10(1):128. https://doi.org/10.3390/ antiox10010128

11. Pham-Huy LA, He H, Pham-Huy C. Free radicals, antioxidants in disease and health. Int J Biomed Sci. 2008;4(2):89-96. PMid:23675073

12. Asmat $\mathrm{U}$, Abad K, Ismail K. Diabetes mellitus and oxidative stress-a concise review. Saudi Pharm J. 2016;24(5):547-53. https://doi.org/10.1016/j.jsps.2015.03.013

PMid:27752226

13. Fuloria S, Subramaniyan V, Karupiah S, Kumari U, Sathasivam K Meenakshi DU. A comprehensive review on source, types, effects, nanotechnology, detection, and therapeutic management of reactive carbonyl species associated with various chronic diseases. Antioxidants. 2020;9(11):1075. https:// doi.org/10.3390/antiox9111075

PMid:33147856

14. Shahreza FD. Oxidative stress, free radicals, kidney disease, and plant antioxidants. Immunopathol Persa. 2016;3(2):1-6. https://doi.org/10.15171/ipp.2017.03

15. Rafieian-Kopaei M, Baradaran A, Rafieian M. Plants antioxidants: From laboratory to clinic. J Nephropathol. 2013;2(2):152-3. https://doi.org/10.5812/nephropathol.12116 PMid:24475444

16. Martins S, Mussatto SI, Martínez-Avila G, Montañez-Saenz J, Aguilar CN, Teixeira JA. Bioactive phenolic compounds: Production and extraction by solid-state fermentation. A review. Biotechnol Adv. 2011;29(3):365-73. https://doi.org/10.1016/j. biotechadv.2011.01.008

17. Llorens J. Toxic neurofilamentous axonopathies-accumulation of neurofilaments and axonal degeneration. J Intern Med. 2013;273(5):478-89. https://doi.org/10.1111/joim.12030 PMid:23331301

18. Subramaniyan V, Kayarohanam S, Kumar A, Kumarasamy V. Impact of herbal drugs and its clinical application. Int $\mathrm{J}$ Res Pharm Sci. 2019;10(2):1340-5. https://doi.org/10.26452/ijrps. v10i2.537

19. Akbarzadeh A, Norouzian D, Mehrabi MR, Jamshidi Sh, Farhangi A, Verdi AA. Induction of diabetes by Streptozotocin in rats. Indian J Clin Biochem. 2007;22(2):60-4. https://doi. 
org/10.1007/bf02913315

PMid:23105684

20. Ikebukuro K, Adachi Y, Yamada Y, Fujimoto S, Seino Y, Oyaizu $\mathrm{H}$. Treatment of streptozotocin-induced diabetes mellitus by transplantation of islet cells plus bone marrow cells via portal vein in rats. Transplantation. 2002;73(4):512-8. https:// doi.org/10.1097/00007890-200202270-00004

PMid:11889421

21. Brereton MF, Iberl M, Shimomura K, Zhang Q, Adriaenssens AE, Proks P. Reversible changes in pancreatic islet structure and function produced by elevated blood glucose. Nat Commun. 2014;5:4639. https://doi.org/10.1038/ncomms5639

PMid:25145789

22. Erejuwa OO, Sulaiman SA, Wahab MS, Salam SK, Salleh MS, Gurtu S. Antioxidant protective effect of glibenclamide and metformin in combination with honey in pancreas of streptozotocin-induced diabetic rats. Int $\mathrm{J}$ Mol Sci. 2010;11(5):2056-66. https://doi.org/10.3390/ijms11052056 PMid:20559501

23. Rahman N, Utami Dewi N, Bohari B. Phytochemical and antioxidant activity of avocado leaf extract (Persea americana mill.). Asian J Sci Res. 2018;11(3):357-63. https://doi. org/10.3923/ajsr.2018.357.363

24. Panche AN, Diwan AD, Chandra SR. Flavonoids: An overview. J Nutr Sci. 2016;5:e47.

\section{PMid:28620474}

25. Kumar S, Pandey AK. Chemistry and biological activities of flavonoids: An overview. ScientificWorldJournal. 2013;2013:162750.

PMid:24470791

26. Dembinska-Kiec A, Mykkänen $O$, Kiec-Wilk B, Mykkänen $H$. Antioxidant phytochemicals against Type 2 diabetes. $\mathrm{Br}$ J Nutr. 2008;99(1):ES109-17. https://doi.org/10.1017/ s000711450896579x PMid:18503731

27. Subramaniyan V, Shaik S, Bag A, Manavalan G, Chandiran S. Potential action of Rumex vesicarius (L.) against potassium dichromate and gentamicin induced nephrotoxicity in experimental rats. Pak J Pharm Sci. 2018;31(2):509-16.

PMid:29618442

28. Rahman N, Sabang SM, Dewi NU, Bohari B, Fitrasyah SI. The dosage of the avocado leaf extract (Persea americana Mill.) on regeneration of diabetic white rats (Rattus norvegicus) renal cell. Int J Nutr Pharmacol Neurol Dis. 2020;10(3):149.

29. Bajaj S, Fuloria S, Subramaniyan V, Meenakshi DU, Wakode S, Kaur A. Chemical characterization and antiinflammatory activity of phytoconstituents from Swertia alata. Plants. 2021;10(6):1109. https://doi.org/10.3390/ plants 10061109

PMid:34072717 